\title{
Sistem Pendukung Keputusan Pemilihan Bibit Karet Menggunakan Metode Simple Additive Weighting (SAW) Berbasis Web
}

\author{
Palma Nobel Perdamaian \\ Politeknik Pertanian Negeri \\ Samarinda Teknologi Rekayasa \\ Perangkat Lunak Manajemen \\ Pertanian \\ Samarinda, Kalimantan Timur \\ palmanobel30@gmail.com
}

\author{
Eny Maria \\ Teknologi Rekayasa Perangkat \\ Lunak \\ Politeknik Pertanian Negeri \\ Samarinda Manajemen Pertanian \\ Samarinda, Kalimantan Timur \\ mariaeny.siringo2@gmail.com
}

\author{
Rusmini \\ Teknologi Rekayasa Perangkat \\ Lunak \\ Politeknik Pertanian Negeri \\ Samarinda Manajemen Pertanian \\ Samarinda, Kalimantan Timur \\ mini9964@rocketmail.com
}

\begin{abstract}
Abstrak - Pemanfaatan sistem pendukung keputusan dengan menggunakan metode Simple Additive Weighting (SAW) sangat tepat jika diterapkan pada permasalahan ini. Metode ini dipilih karena mampu menyelesaikan dan memberikan hasil yang terbaik dari sejumlah alternatif yang dimaksudkan yaitu bibit karet unggul dan kriteriakriteria yang ditentukan. Penelitian dilakukan dengan mencari kriteria-kriteria dan nilai bobot untuk setiap atribut, kemudian dilakukan proses perhitungan. Tujuan dari penelitian ini adalah membuat suatu sistem pendukung keputusan yang mampu membantu dalam menentukan pemilihan bibit karet yang unggul berdasarkan kriteria yang telah ditentukan. Hasil penelitian ini didapatkan bahwa nilai tertinggi dari 5 bibit yang diuji adalah bibit 1 dengan nilai peferensi 1 .
\end{abstract}

Kata Kunci-Sistem Pendukung Keputusan, Bibit Karet, Simple additive Weighting ( $S A W)$.

\section{PENDAHULUAN}

Perkebunan Indonesia telah melewati perjalanan sejarah yang panjang. Lebih dari lima abad yang lalu lautan nusantara telah ramai oleh lalu lintas perdagangan komoditas utama produk perkebunan, seperti lada, pala, cengkeh dan rempah-rempah selanjutnya berkembang berbagai komoditas tambahan seperti kopi, kelapa sawit, kakao, dan karet.

Tanaman karet (Hevea brasiliensis) merupakan salah satu komoditi hasil perkebunan yang mempunyai peran cukup penting dalam kegiatan perekonomian di Indonesia. Karet juga salah satu komoditas ekspor Indonesia yang cukup penting sebagai penghasil devisa negara selain minyak dan gas. Indonesia merupakan negara produsen dan eksportir karet terbesar dunia. Tahun 2016 luas areal PBN (Perkebunan Besar Negara) karet Indonesia tercatat 229,85 ribu ha dan luas areal PBS (Perkebunan Besar Swasta) karet Indonesia tercatat 315,05 ribu ha (BPS,2016). Berdasarkan data di atas dapat disimpulkan bahwa perkembangan penanaman karet di Indonesia dari tahun ke tahun selalu meningkat. Langkah awal pengusahaan usaha tani karet yang baik adalah petani karet perlu untuk menggunakan bahan tanam (bibit) karet yang berkualitas dan mampu menghasilkan lateks yang tinggi. Mengingat amat pentingnya bibit dalam menentukan perbaikan pembangunan perkebunan karet, maka usahatani pembibitan perlu dikelola dengan baik. Bibit karet berkualitas yang digunakan akan menghasilkan tanaman karet yang berkualitas pula.

Kemajuan teknologi saat ini memungkinkan untuk mengakses informasi dari berbagi tempat melalui internet. Pemanfaatan teknologi tidak hanya sebatas pengolahan data saja tetapi juga dimanfaatkan sebagai pemberi solusi terhadap masalah yang diberikan seperti halnya sistem pendukung keputusan yang dapat digunakan untuk membantu para petani karet dalam memilih bibit yang baik. Sistem Pendukung Keputusan merupakan suatu sistem interaktif yang mendukung keputusan dalam proses pengambilan keputusan melalui alternatif-alternatif yang diperoleh dari hasil pengolahan data, informasi dan rancangan model.

Sistem pendukung keputusan yang saat ini berkembang dengan bermacam-macam metodenya yang salah satunya adalah metode SAW (Simple Additive Weighting). Oleh karena itu penulis tertarik membuat skripsi tentang "Sistem Pendukung Keputusan Pemilihan Bibit Karet Berbasis Web Menggunakan Metode Simple Additive Weighting (SAW)". Penulis memilih metode SAW dalam pengambilan keputusan pemilihan bibit karet, karena metode ini mencari penjumlahan terbobot dari rating kinerja pada setiap alternatif pada semua atribut.

\section{TINJAUAN PUSTAKA}

\section{A. Kajian Ilmiah}

Menurut Yusro dan Rahmiati (2016) dalam penelitian yang berjudul Sistem Pendukung Keputusan Pembelian Karet Berdasarkan Kualitas Menggunakan Metode SAW (Simple Additive Weighting) PT. Bengkinang Pekanbaru membahas mengenai sistem pendukung keputusan yang dapat mengetahui bokar yang mengandung zat bercampuran yang dinyatakan karet berkualitas buruk dan berkualitas baik dinyatakan diterima untuk membantu pihak perusahaan dalam pembelian kualitas karet yang bermutu dengan mengevaluasi pemilihan interaktif. 
Menurut Ariyanto (2012) dalam penelitian yang berjudul Sistem Pendukung Keputusan Pemilihan Karyawan Terbaik Dengan Metode SAW (Simple Additive Weighting) Studi Kasus di Pamella Swalayan membahas tentang prosedur penilaian dan pemilihan karyawan terbaik pada Pamella Swalayan Yogyakarta. Sistem ini dikembangkan dengan bahasa pemrograman Delphi 7.0 dan MySQL. Sistem informasi ini dapat digunakan untuk mengolah data karyawan mulai dari proses karyawan masuk, proses penilaian karyawan, proses pemilihan karyawan terbaik, sampai dengan proses pembuatan laporan nilai karyawan.

Menurut Rachman, dkk. (2017) dalam penelitian yang berjudul Sistem Pendukung Keputusan Pemilhan Bibit Cabai Rawit Menggunakan Metode Simple Additive Weighting (SAW) Berbasis Web untuk merancang dan membangun sistem yang dapat memudahkan petani cabai dalam melakukan pemilihan bibit cabai rawit terbaik yang akan dibudidayakan berdasarkan hasil perangkingan bobot bibit cabai yang telah diuji.

Menurut Hidayat dan Baihaqi (2016) dalam penelitian yang berjudul Sistem Pendukung Keputusan Untuk Pemilihan Hotel dengan Simple Additive Weighting (SAW) Berbasis Web membahas tentang SPK pemilihan hotel berbasis web yang dihasilkan dapat digunakan untuk membantu pencarian dan pemilihan hotel bagi pengunjung secara online. Database hotel diambil atau diintegrasikan dengan data hotel yang tersedia di tiket.com.

Berdasarkan uraian dari penelitian dan jurnal sebelumnya, sistem yang akan dibuat memiliki kelebihan yakni objek yang akan diangkat berbeda dengan penelitian sebelumnya.

\section{B. Karet}

Tanaman karet (Havea brasiliensis) berasal dari negara Brazil. Tanaman ini merupakan sumber utama bahan tanaman karet alam dunia. Jauh sebelum tanaman karet ini dibudidayakan, penduduk asli berbagai tempat seperti: Amerika Serikat, Asia dan Afrika Selatan menggunakan pohon lain yang juga menghasilkan getah. Getah yang mirip lateks juga dapat diperoleh dari tanaman Castillaelastica (family moraceae). Sekarang tanaman tersebut kurang dimanfaatkan lagi getahnya karena tanaman karet telah dikenal secara luas dan banyak dibudidayakan. Sebagai penghasil lateks tanaman karet dapat dikatakan satu-satunya yang dikebunkan secara besar-besaran.Tanaman karet merupakan tanaman tahunan yang dapat tumbuh sampai umur 30 tahun (Budiman, 2012)

\section{Sistem Pendukung Keputusan}

Menurut Subakti (2002) sistem pendukung keputusan defenisi awalnya adalah suatu sistem yang ditujukan untuk mendukung manajemen pengambilan keputusan. Defenisi lain Sistem Pendukung Keputusan adalah sistem tambahan, mampu untuk mendukung analisis data secara ad hoc dan pemodelan keputusan, berorientasi pada perencanaan masa depan, dan digunakan pada nterval yang tak teratur atau tak terencanakan.

Sistem pendukung keputusan adalah sistem berbasis komputer yang terdiri 2 komponen interaktif:

a. Sistem bahasa, mekanisme yang menyediakan komunikasi diantara user dengan komponen dalam SPK.

b. Knowledge system, penyimpanan knowledge domain permasalahan yang ditanamkan dalam SPK, baik sebagai data ataupun prosedur.

Sistem pemrosesan permasalahan, link diantara dua komponen, mengandung satu atau lebih kemampuan memanipulasi masalah yang dibutuhkan untuk pengambilan keputusan.

\section{Metode Simple Additive Weighting $(S A W)$}

Metode SAW singkatan dari kata Simple Additive Weighting. Metode SAW merupakan salah satu metode Multiple Attribute Decision Making (MADM). Metode SAW sering juga dikenal istilah metode penjumlahan terbobot dari rating kinerja pada setiap alternatif pada semua atribut.

Tahapan-tahapan dalam metode SAW adalah sebagai berikut:

a. Menentukan alternatif (A)

b. Menentukan kriteria-kriteria untuk pemilihan beberapa alternatif ( $\mathrm{Cij}$ )

c. Memberikan nilai rating kecocokan dari setiap alternatif pada setiap kriteria

d. Menentukan nilai bobot preferensi atau tingkat kepentingan untuk masing-masing kriteria (W)

$$
\mathrm{W}=\left[\mathrm{W}_{1} \mathrm{~W}_{2} \mathrm{~W}_{3} \mathrm{~W}_{\mathrm{j}}\right.
$$

e. Membuat tabel rating kecocokan dari setiap alternatif pada setiap kriteria.

f. Membuat matriks keputusan X yang dibentuk dari tabel rating kecocokan dari setiap alternatif pada setiap kriteria. Nilai x setiap alternatif (Ai) pada setiap criteria $(\mathrm{Cj})$ yang sudah ditentukan, dimana, $i=1,2, \ldots m$ dan $j=1,2, \ldots n$.

$$
X=\left[\begin{array}{cccc}
X_{11} & X_{12} & \ldots & X_{1 j} \\
\vdots & \vdots & \vdots & \vdots \\
X_{\mathrm{i} 1} & X_{\mathrm{i} 2} & \ldots & X_{\mathrm{ij}}
\end{array}\right]
$$

g. Melakukan normalisasi matrik keputusan dengan cara menghitung nilai rating kinerja ternomalisasi (rij) dari alternatif Ai pada kriteria $\mathrm{Cj}$ dengan rumus:

$$
\begin{aligned}
& \mathrm{r}_{\mathrm{ij}}=\frac{\mathrm{x}_{\mathrm{ij}}}{\operatorname{Max}\left(\mathrm{x}_{\mathrm{ij}}\right)} \text { Jikajadalah atribut benefit } \\
& \mathrm{r}_{\mathrm{ij}}=\frac{\operatorname{Min}\left(\mathrm{x}_{\mathrm{ij}}\right)}{\mathrm{x}_{\mathrm{ij}}} \text { Jikaj adalah atribut cost }
\end{aligned}
$$

Keterangan :

1) Dikatakan kriteria keuntungan apabila nilai $\mathrm{x}_{\mathrm{ij}}$ memberikan keuntungan bagi penganbil keputusan, sebaliknya kriteria biaya apabila $\mathrm{x}_{\mathrm{ij}}$ menimbulkan biaya bagi pengambil keputusan. 
2) Apabila berupa kriteria keuntungan maka nilai $\mathrm{x}_{\mathrm{ij}}$ dibagi dengan nilai $\operatorname{Max}_{i}\left(\mathrm{x}_{\mathrm{ij}}\right)$ dari setiap kolom, sedangkan untuk kriteria biaya, nilai $\operatorname{Min}_{i}\left(\mathrm{x}_{\mathrm{ij}}\right)$ dari setiap kolom dibagi dengan nilai $\mathrm{x}_{\mathrm{ij}}$.

h. Hasil dari nilai rating kinerja ternormalisasi $\left(r_{i j}\right)$ membentuk matrik ternormalisasi $(\mathrm{R})$

$$
R=\left[\begin{array}{cccc}
r_{11} & r_{12} & \ldots & r_{1 j} \\
\vdots & \vdots & \vdots & \vdots \\
r_{11} & r_{i 2} & \ldots & r_{i j}
\end{array}\right]
$$

i. Hasil akhir nilai preferensi $\left(\mathrm{V}_{\mathrm{i}}\right)$ diperoleh dari penjumlahan dari perkalian elemen baris matriks ternormalisasi (R) dengan bobot preferensi (W) yang bersesuaian elemen kolom matrik $(\mathrm{W})$.

$$
V_{\mathrm{i}}=\sum_{j=1}^{n} W_{j} r_{\mathrm{i} j}
$$

Hasil perhitungan nilai $\mathrm{V}_{\mathrm{i}}$ yang lebih besar mengindikasikan bahwa alternatif $\mathrm{A}_{\mathrm{i}}$ merupakan alternative terbaik (Kusumadewi,2006).

\section{METODE PENELITIAN}

\section{A. Prosedur Penelitian}

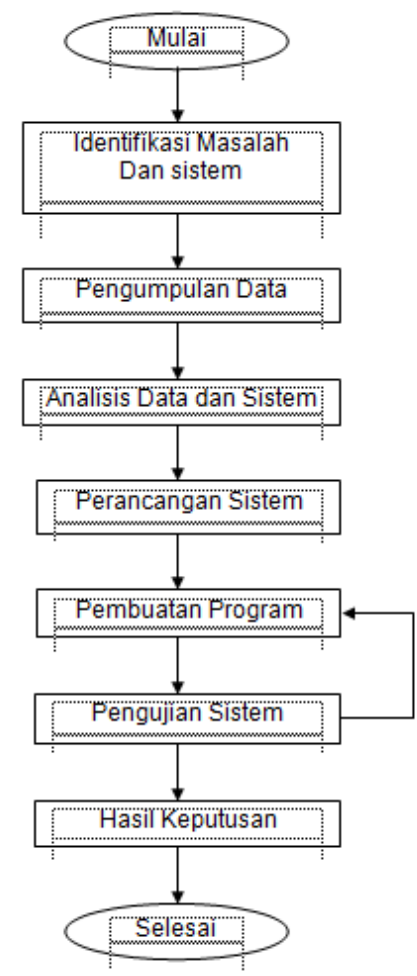

Gambar 1. Prosedur Penelitian

\section{B. Perhitungan dengan Metode SAW}

Data alternatif adalah data yang diperoleh dari pengambilan data ke lapangan secara langsung. Data yang diambil merupakan data bibit karet jenis PB 260 dengan profil sebagai berikut:

\section{1) Bentuk Payung}

Bentuk payung dari bibit jenis PB 260 adalah setengah lingkaran

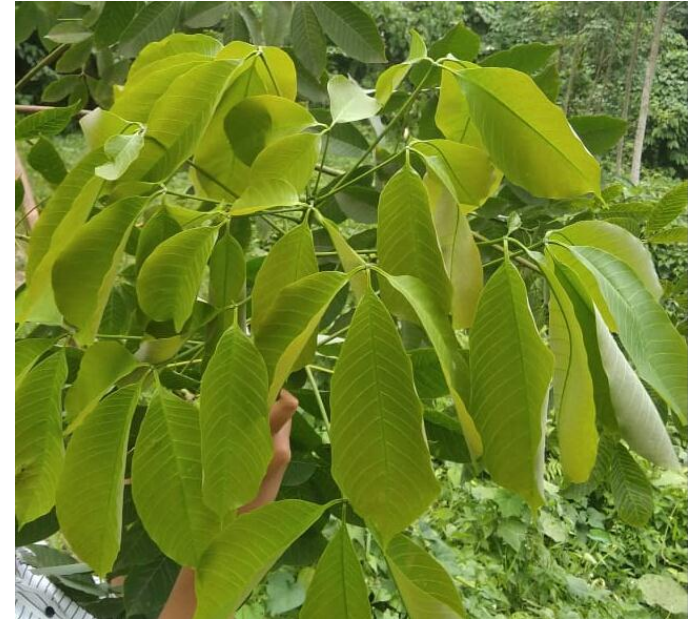

Gambar 2. Bentuk Payung

\section{2) Tangkai Daun}

Tangkai daun dari bibit jenis PB 260 yakni posisi tangkai daun yang horizontal dan bentuk tangkai daun lurus

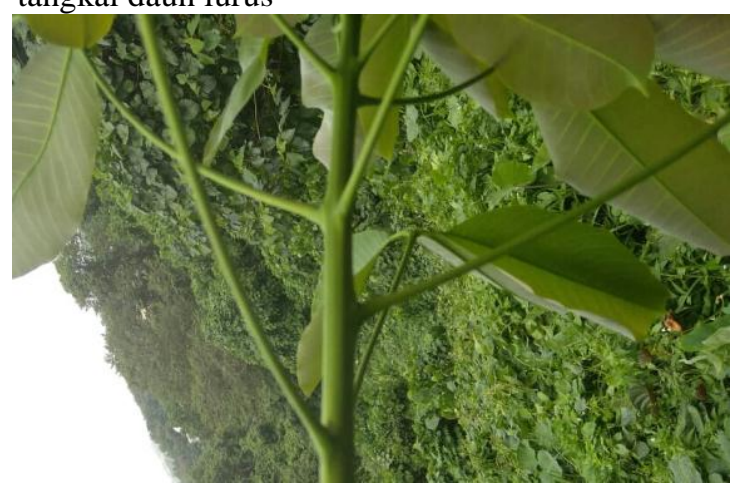

Gambar 3. Tangkai Daun

\section{3) Helai Daun}

Helai daun dari jenis bibit PB 260 yang baik adalah yang memiliki warna hijau, bentuk daun oval, tulang daun menyirip dan ketebalan daun 0,21-0,24 $\mathrm{mm}$.

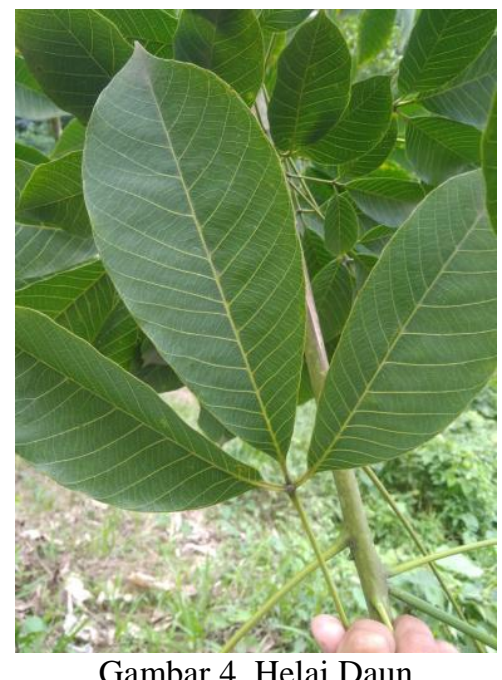

Gambar 4. Helai Daun 
Data alternatif yang akan dihitung menggunakan metode SAW dapat dilihat pada Tabel 1 berikut:

Tabel 1. Data Alternatif

\begin{tabular}{|c|c|c|c|c|c|c|c|c|}
\hline \multirow{3}{*}{ No } & \multirow{3}{*}{ Bibit } & \multicolumn{7}{|c|}{ Kriteria } \\
\hline & & \multirow{2}{*}{$\begin{array}{l}\text { Bentuk } \\
\text { Payung }\end{array}$} & \multicolumn{2}{|c|}{ Tangkai Daun } & \multicolumn{4}{|c|}{ Helai Daun } \\
\hline & & & Posisi & Bentuk & Warna & Bentuk & Tulang & Ketebalan \\
\hline 1 & Bibit 1 & $\begin{array}{l}\text { setengah } \\
\text { lingkaran }\end{array}$ & horizontal & lurus & hijau & oval & menyirip & 0.2225 \\
\hline 2 & Bibit 2 & $\begin{array}{l}\text { setengah } \\
\text { lingkaran }\end{array}$ & horizontal & lurus & hijau & oval & menyirip & 0.2075 \\
\hline 3 & Bibit 3 & $\begin{array}{l}\text { setengah } \\
\text { lingkaran }\end{array}$ & horizontal & Iurus & hijau & oval & menyirip & 0.255 \\
\hline 4 & Bibit 4 & $\begin{array}{l}\text { setengah } \\
\text { lingkaran }\end{array}$ & horizontal & lurus & hijau & oval & menyirip & 0.2625 \\
\hline 5 & Bibit 5 & $\begin{array}{l}\text { setengah } \\
\text { lingkaran }\end{array}$ & horizontal & lurus & $\begin{array}{c}\text { hijau } \\
\text { kekuning } \\
\text { kuningan }\end{array}$ & oval & menyirip & 0.215 \\
\hline
\end{tabular}

Bobot kriteria merupakan nilai setiap kriteria yang telah ditentukan berdasarkan hasil wawancara dengan para ahli.

Tabel 2. Data Bobot Kriteria

\begin{tabular}{|c|c|c|c|c|c|}
\hline No & Kriteria & Bobot & Subkriteria & Bobot & Atribut \\
\hline 1 & $\begin{array}{l}\text { Bentuk } \\
\text { Payung }\end{array}$ & 0,3 & & & Benefit \\
\hline \multirow[t]{2}{*}{2} & \multirow{2}{*}{ Tangkai daun } & \multirow[t]{2}{*}{0,2} & Posisi & 0,1 & Benefit \\
\hline & & & Bentuk & 0,1 & Benefit \\
\hline \multirow{4}{*}{3} & \multirow{4}{*}{ Helai Daun } & \multirow{4}{*}{0,5} & Warna & 0,3 & Benefit \\
\hline & & & Bentuk Daun & 0,1 & Benefit \\
\hline & & & Tulang Daun & 0,05 & Benefit \\
\hline & & & Ketebalan & 0,05 & Benefit \\
\hline
\end{tabular}

Nilai alternatif akan dikonversi oleh sistem kedalam nilai angka yang telah ditentukan.

Tabel 3. Konversi Nilai Alternatif

\begin{tabular}{|c|c|c|c|c|c|c|c|c|}
\hline \multirow{3}{*}{ No } & \multirow{3}{*}{ Bibit } & \multicolumn{7}{|c|}{ Kriteria } \\
\hline & & \multirow{2}{*}{$\begin{array}{l}\text { Bentuk } \\
\text { Payung }\end{array}$} & \multicolumn{2}{|c|}{ Tangkai Daun } & \multicolumn{4}{|c|}{ Helai Daun } \\
\hline & & & Posisi & Bentuk & Warna & Bentuk & Tulang & Ketebalan \\
\hline 1 & Bibit 1 & 0.15 & 0.075 & 0.05 & 0.25 & 0.09 & 0.04 & 0.025 \\
\hline 2 & Bibit 2 & 0.15 & 0.075 & 0.05 & 0.25 & 0.09 & 0.04 & 0.015 \\
\hline 3 & Bibit 3 & 0.15 & 0.075 & 0.05 & 0.25 & 0.09 & 0.04 & 0.015 \\
\hline 4 & Bibit 4 & 0.15 & 0.075 & 0.05 & 0.25 & 0.09 & 0.04 & 0.015 \\
\hline 5 & Bibit 5 & 0.15 & 0.075 & 0.05 & 0.05 & 0.09 & 0.04 & 0.025 \\
\hline
\end{tabular}

Pada sistem yang akan dibangun semua kriteria memiliki atribut benefit. Oleh karena itu setiap nilai kriteria dari alternatif akan dikalikan dengan nilai maksimal dari nilai kriteria yang ada.

Tabel 4. Nilai Normalisasi

\begin{tabular}{|c|c|c|c|c|c|c|c|c|}
\hline \multirow{3}{*}{$\begin{array}{l}\mathrm{N} \\
\mathrm{o}\end{array}$} & \multirow{3}{*}{ Bibit } & \multicolumn{7}{|c|}{ Kriteria } \\
\hline & & \multirow{2}{*}{$\begin{array}{l}\text { Bentuk } \\
\text { Payung }\end{array}$} & \multicolumn{2}{|c|}{ Tangkai Daun } & \multicolumn{4}{|c|}{ Helai Daun } \\
\hline & & & Posisi & Bentuk & Warna & Bentuk & Tulang & Ketebalan \\
\hline 1 & Bibit 1 & 1 & 1 & 1 & 1 & 1 & 1 & 1 \\
\hline 2 & Bibit 2 & 1 & 1 & 1 & 1 & 1 & 1 & 0.4 \\
\hline 3 & Bibit 3 & 1 & 1 & 1 & 1 & 1 & 1 & 0.6 \\
\hline 4 & Bibit 4 & 1 & 1 & 1 & 1 & 1 & 1 & 0.6 \\
\hline 5 & Bibit 5 & 1 & 1 & 1 & 0,2 & 1 & 1 & 1 \\
\hline
\end{tabular}

Pada tahap ini semua nilai kriteria dari suatu alternatif akan dikalikan dengan nilai bobot dari kriteria tersebut.

Tabel 4. Nilai Perkalian Bobot

\begin{tabular}{|c|c|c|c|c|c|c|c|c|}
\hline \multirow{3}{*}{$\begin{array}{l}\mathrm{N} \\
\mathrm{o}\end{array}$} & \multirow{3}{*}{ Bibit } & \multicolumn{7}{|c|}{ Kriteria } \\
\hline & & \multirow{2}{*}{$\begin{array}{l}\text { Bentuk } \\
\text { Payung }\end{array}$} & \multicolumn{2}{|c|}{ Tangkai Daun } & \multicolumn{4}{|c|}{ Helai Daun } \\
\hline & & & Posisi & Bentuk & Warna & Bentuk & Tulang & Ketebalan \\
\hline 1 & Bibit 1 & 0.3 & 0.1 & 0.1 & 0.3 & 0.1 & 0.05 & 0.05 \\
\hline 2 & Bibit 2 & 0.3 & 0.1 & 0.1 & 0.3 & 0.1 & 0.05 & 0.02 \\
\hline 3 & Bibit 3 & 0.3 & 0.1 & 0.1 & 0.3 & 0.1 & 0.05 & 0.03 \\
\hline 4 & Bibit 4 & 0.3 & 0.1 & 0.1 & 0.3 & 0.1 & 0.05 & 0.03 \\
\hline 5 & Bibit 5 & 0.3 & 0.1 & 0.1 & 0.06 & 0.1 & 0.05 & 0.05 \\
\hline
\end{tabular}

Setelah menghitung nilai bobot maka semua nilai kriteria dari satu alternatif dijumlahkan.

Tabel 5. Nilai Preferensi

\begin{tabular}{|c|c|c|}
\hline No & Bibit & Total \\
\hline 1 & Bibit 1 & 1 \\
\hline 2 & Bibit 2 & 0.97 \\
\hline 3 & Bibit 3 & 0.98 \\
\hline 4 & Bibit 4 & 0.98 \\
\hline 5 & Bibit 5 & 0,76 \\
\hline
\end{tabular}

Tabel 6. Perankingan

\begin{tabular}{|c|c|c|}
\hline No & Bibit & Total \\
\hline 1 & Bibit 1 & 1 \\
\hline 2 & Bibit 3 & 0,98 \\
\hline 3 & Bibit 4 & 0.98 \\
\hline 4 & Bibit 2 & 0.97 \\
\hline 5 & Bibit 5 & 0,76 \\
\hline
\end{tabular}

Berdasarkan hasil perhitungan diatas maka dapat disimpulkan bahwa pada perhitungan metode SAW dengan atribut benefit yang menjadi bibit unggul adalah Bibit 1 dengan nilai preferensi 1 Berdasarkan fakta di lapangan yang menjadi bibit unggul berdasarkan kriteria adalah Bibit 1. Maka, dalam pengembangan sistem yang digunakan adalah atribut benefit.

\section{HASIL DAN PEMBAHASAN}

\section{A. Hasil Pengembangan Sistem}

\section{1) Halaman Home}

Halaman Home merupakan tampian awal aplikasi Sistem Pendukung Keputusan Pemilihan Bibit Karet.

Sistem Pendukung Keputusan Pemilihan Bibit Karet Metode SAW

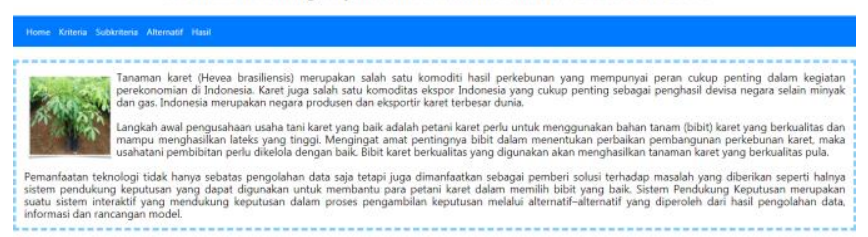

Gambar 5. Halaman Home 
Pada halaman data kriteria terdapat tabel yang berisi kriteria bibit karet beserta atribut dan bobotnya.

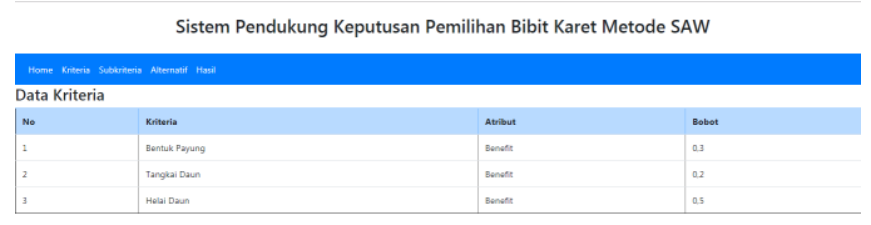

Gambar 6. Halaman Data Kriteria

\section{3) Halaman Data Subkriteria}

Pada halaman data subkriteria terdapat tabel yang berisi data kriteria, data subkriteria, atribut dan bobot.

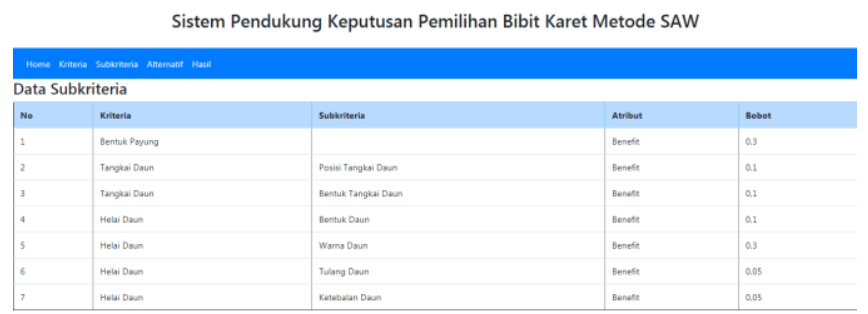

\section{Gambar 7. Halaman Data Subkriteria}

\section{4) Halaman Alternatif}

Pada halaman alternatif terdapat data alternative yang telah di inputkan. Terdapat juga button untuk menginput data alternatif yang baru.

Sistem Pendukung Keputusan Pemilihan Bibit Karet Metode SAW

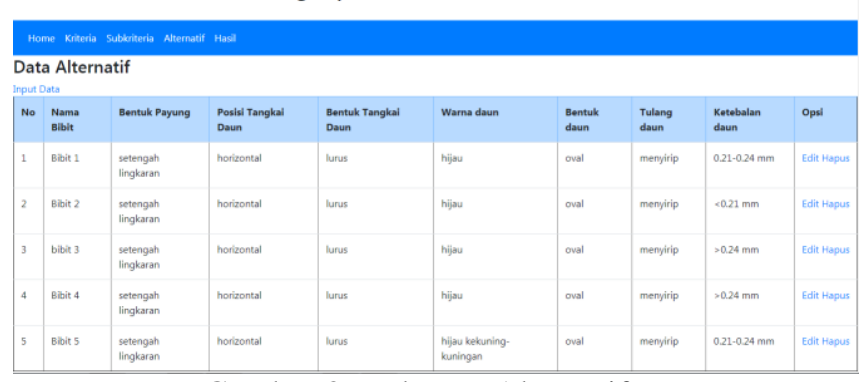

Gambar 8. Halaman Alternatif

\section{5) Halaman Hasil}

Pada halaman hasil terdapat tabel hasil konversi alternatif yang telah diinputkan, tabel normalisasi, tabel perkalian bobot, tabel nilai preferensi, dan tabel perankingan.
Sistem Pendukung Keputusan Pemilihan Bibit Karet Metode SAW

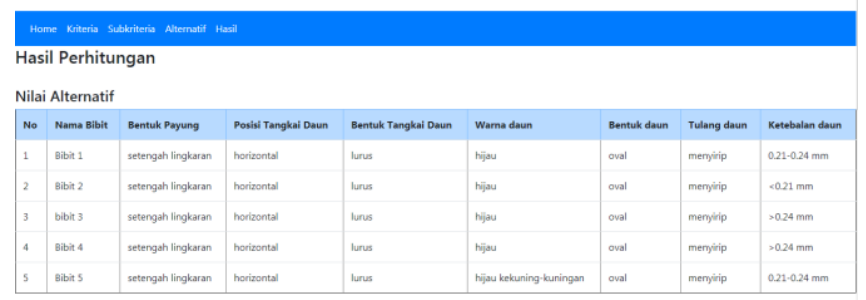

Gambar 9. Tabel Nilai Alternatif Pada Halaman Hasil

b) Tabel Nilai Konversi

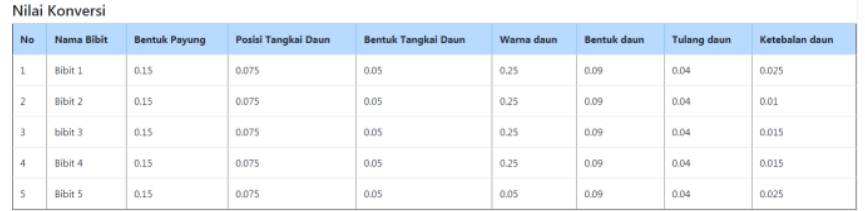

Gambar 10. Tabel Nilai Konversi Pada Halaman Hasil

c) Tabel Nilai Normalisasi

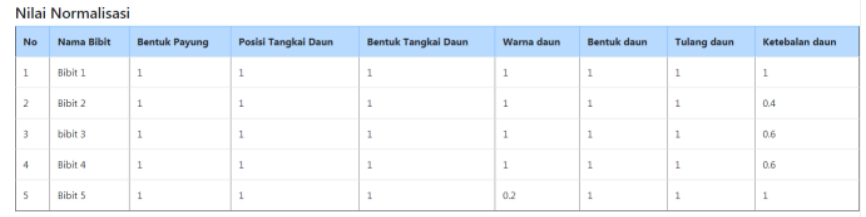

Gambar 11. Tabel Nilai Normalisasi Pada Halaman Hasil

d) Tabel Nilai Preferensi

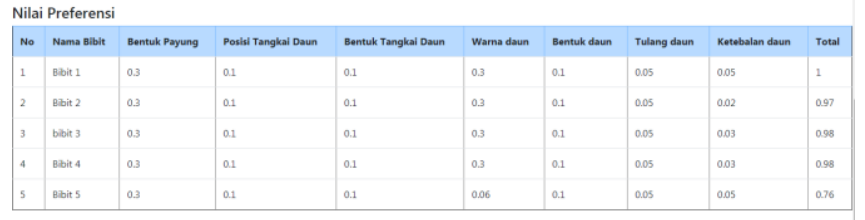

Gambar 12. Tabel Nilai Preferensi Pada Halaman Hasil

\section{KESIMPULAN}

Kesimpulan dari hasil perancangan dan implementasi sistem pendukung keputusan pemilihan bibit karet adalah Sistem pendukung keputusan dapat melakukan pengambilan keputusan dengan menghitung nilai normalisasi dan perkalian bobot pada masing-masing kriteria dan subkriteria dari setiap alternatif sehingga dapat diberikan keputusan pemilihan bibit yang baik. Untuk bibit yang unggul adalah bibit dengan kriteria bentuk payung setengah lingkaran, posisi tangkai daun horizontal, bentuk tangkai daun lurus, warna daun hijau, bentuk daun oval, tulang daun menyirip dan ketebalan daun 0,21-0,24 mm. berdasarkan hasil pengujian sistem bibit yang unggul adalah Bibit 1 dengan nilai preferensi 1. Adapun saran-saran dari penulis untuk sistem ini adalah Bagi peneliti yang akan datang dapat mengembangkan sistem dengan menggunakan metode yang lain namun tetap konsisten pada pokok permasalahan dengan penentuan bobot kriteria sehingga menghasilkan keputusan akurat. Mengembangkan sistem

a) Tabel Nilai Alternatif 
dengan menambahkan kriteria, menambahkan atribut cost, dan spesifik pada jenis klon bibit karet.

\section{DAFTAR PUSTAKA}

Ariyanto. 2012. "Sistem Pendukung Keputusan Pemilihan Karyawan Terbaik dengan Metode SAW (Simple Additive Weighting) Studi Kasus di Pamella Swalayan". Yogyakarta: Fakultas Sains dan Teknologi Universitas Islam Negeri Sunan Kalijaga.

Badan Pusat Statistik. 2016. Statistik Karet Indonesia. Katalog:5504002

Budiman H. 2012. Budidaya Karet Unggul. Pustaka Baru Press, Yogyakarta. Hal 1-2.

Hidayat M. dan Baihaqi M.A.M. 2016. "Sistem Pendukung Keputusan untuk Pemilihan Hotel dengan Simple Additive Weighting (SAW) Berbasis Web”. Seminar Nasional Teknologi Informasi dan Multimedia 2016. ISSN.2302-3805:61-66.

Hidayatullah P. dan Kawistara J.K. 2014. Pemrograman WEB. Informatika Bandung, Bandung. Hal 13.
Kusumadewi., Sri., Hartati S., Harjoko A. dan Wardoyo R. 2006. Fuzzy Multi-Attribute Decision Making (Fuzzy MADM). Graha Ilmu, Yogyakarta.

Rachman W.H., Widians J.A. dan Masnawati. 2017. "Sistem Pendukung Keputusan Pemilihan Bibit Cabai Rawit Menggunakan Metode Simple Additive Weighting (SAW) Berbasis Web. Prosiding Semiar Ilmu Komputer dan Teknologi Informasi. Vol.2, No.1:175-181.

Rasjid F.E. 2014. Bahasa Pemrograman Populer PHP. https://www.ubaya.ac.id (diunduh 30 September 2018).

Ratnasari E. 2017. Pengertian dan Fungsi Xampp. https://ilmuti.org (diunduh 30 Maret 2019).

Subakti I. 2002. Sistem Pendukung Keputusan. Surabaya: Fakultas Teknologi Informasi Institut Teknologi Sepuluh Nopember.

Yusro N. dan Rahmiati. 2016. "Sistem Pendukung Keputusan Pembelian Karet Berdasarkan Kualitas Menggunakan Metode SAW (Simple Additive Weighting) PT Bengkinang Pekanbaru”. Jurnal Ilmiah Media Processor. Vol.11, No.1:731-741. 